конф. (Симферополь, 9-11 октября 2018 г.) / под ред. В. В. Орехова, Е. Я. Титаренко. Симферополь, 2018. С. 275-278.

DOI 10.31168/7996-2700-3.122

\author{
Самуэла Томасик \\ Университет Казимира Великого \\ Быдгощ, Польша \\ s.tomasik@yandex.ru
}

\title{
Место названий пандемических заболеваний в ономастической системе
}

Пандемия — это явление, характеризующееся распространением инфекционного заболевания на большой территории, например всей страны или континента. Обычно пандемией считается болезнь, поражающая значительную часть населения.

Всемирная история показывает, что человечество не раз страдало от пандемических заболеваний. Проблема их названий до сих пор не была достаточно разработана. Целью доклада является определение их места в ономастической системе, их системно-языковой и мотивационный анализ.

Во время первых случаев регистрации заболеваний особое название им, конечно, не присваивается. Оно чаще всего появляется после постановки сотен или тысяч похожих диагнозов, когда болезнью охвачено население большой территории. В этот момент можно говорить о возникновении онимического объекта. При этом новое название распространяется также и на случаи предыдущего этапа — время начала роста заболеваний.

Названия пандемий во многих случаях выполняют информативную функцию. Чаще всего эта информация касается происхождения патогена, вызывающего болезнь, и охваченной им территории. Надо обратить внимание, что, как в случае с традиционными классами имен собственных, название пандемии является вторичным по отношению к именуемому объекту.

(C) Томасик С., 2019 
Проприальный характер данных единиц, кажется, не вызывает сомнений. Название пандемии позволяет безошибочно определить онимический объект и его характерные черты; оно отсылает к определенному историческому событию, однозначно ассоциируется с определенной территорией, может также непосредственно служить источником информации о соматических симптомах, характерных для данного заболевания. В то же время при анализе единиц такого типа нелегко определить их место в ономастической системе; неясно, следует ли считать их именами собственными исторических событий либо именами собственными болезней.

DOI $10.31168 / 7996-2700-3.123$

\author{
Е. С. Узенёва \\ Институт славяноведения РАН \\ Москва, Россия \\ lenuzen@mail.ru
}

\title{
О языке и культуре славян-мусульман Северной Греции: случай Ксанти
}

В докладе будут представлены предварительные итоги исследования современного состояния языка и традиционной культуры одного из архаических анклавов Балканского полуострова - округа Ксанти, где в горах компактно проживают славяне-мусульмане, помаки (этнические болгары), представляющие собой миноритарную этноязыковую и культурно-конфессиональную группу, существующую в течение длительного времени в иноязычном и инорелигиозном окружении (православные греки).

Автор опирается на собственные полевые материалы, собранные во время двух этнолингвистических экспедиций, осуществленных в 2018 и 2019 гг. совместно с К. А. Климовой, доцентом кафедры новогреческой филологии филологического факультета МГУ им. М. В. Ломоносова. Всего было обследовано 13 сел, опрошено 35 информантов в возрасте 18-75 лет.

(C) Узенёва Е. С., 2019 